
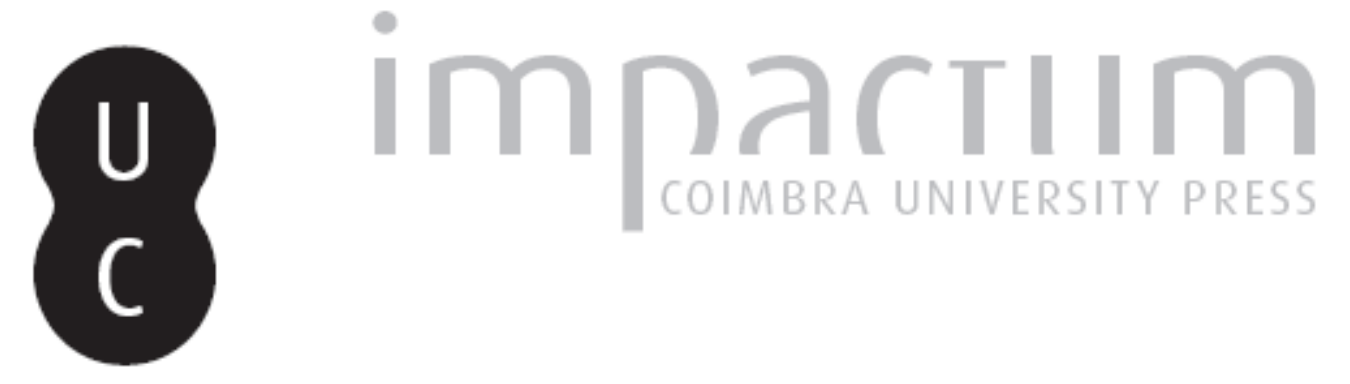

\title{
Doutrinas e profilaxia da tuberculose em Portugal nos finais do século XIX
}

Autor(es): Vieira, Ismael Cerqueira

Publicado por: Centro de História da Sociedade e da Cultura

URL persistente:

URI:http://hdl.handle.net/10316.2/39397

DOI:

DOI:http://dx.doi.org/10.14195/1645-2259_13_15

Accessed : $\quad$ 26-Apr-2023 13:02:56

A navegação consulta e descarregamento dos títulos inseridos nas Bibliotecas Digitais UC Digitalis, UC Pombalina e UC Impactum, pressupõem a aceitação plena e sem reservas dos Termos e Condições de Uso destas Bibliotecas Digitais, disponíveis em https://digitalis.uc.pt/pt-pt/termos.

Conforme exposto nos referidos Termos e Condições de Uso, o descarregamento de títulos de acesso restrito requer uma licença válida de autorização devendo o utilizador aceder ao(s) documento(s) a partir de um endereço de IP da instituição detentora da supramencionada licença.

Ao utilizador é apenas permitido o descarregamento para uso pessoal, pelo que o emprego do(s) título(s) descarregado(s) para outro fim, designadamente comercial, carece de autorização do respetivo autor ou editor da obra.

Na medida em que todas as obras da UC Digitalis se encontram protegidas pelo Código do Direito de Autor e Direitos Conexos e demais legislação aplicável, toda a cópia, parcial ou total, deste documento, nos casos em que é legalmente admitida, deverá conter ou fazer-se acompanhar por este aviso.

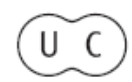



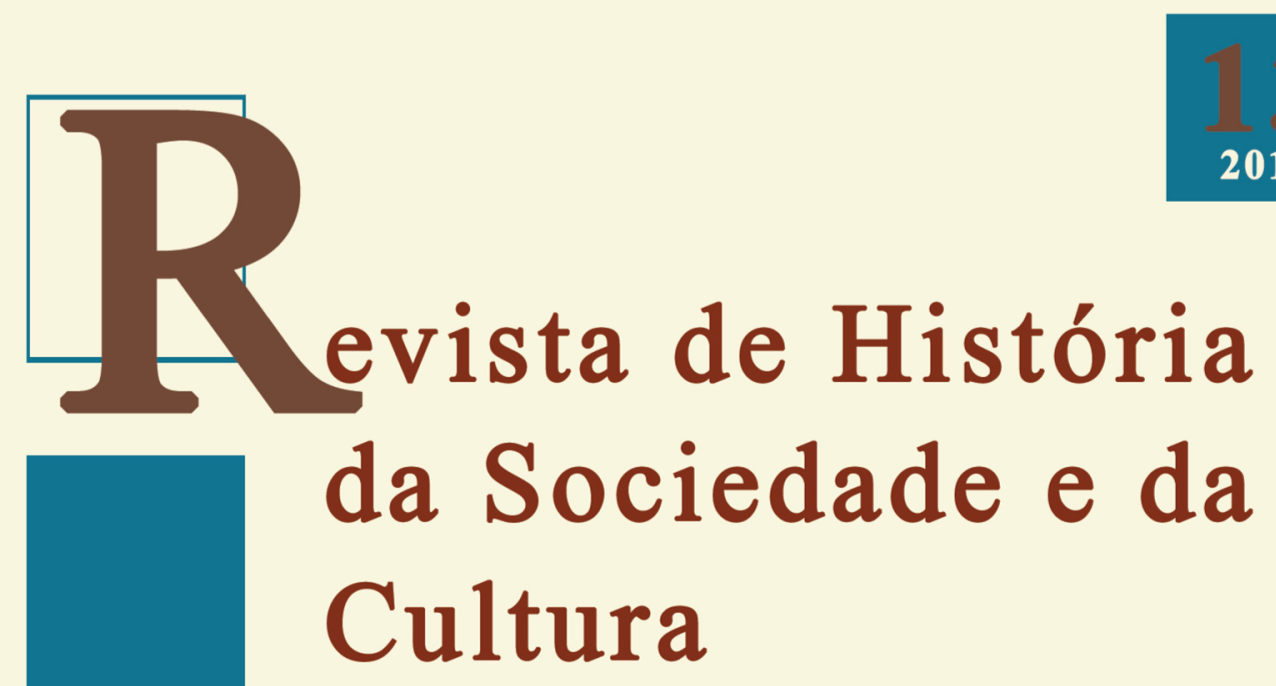

2013

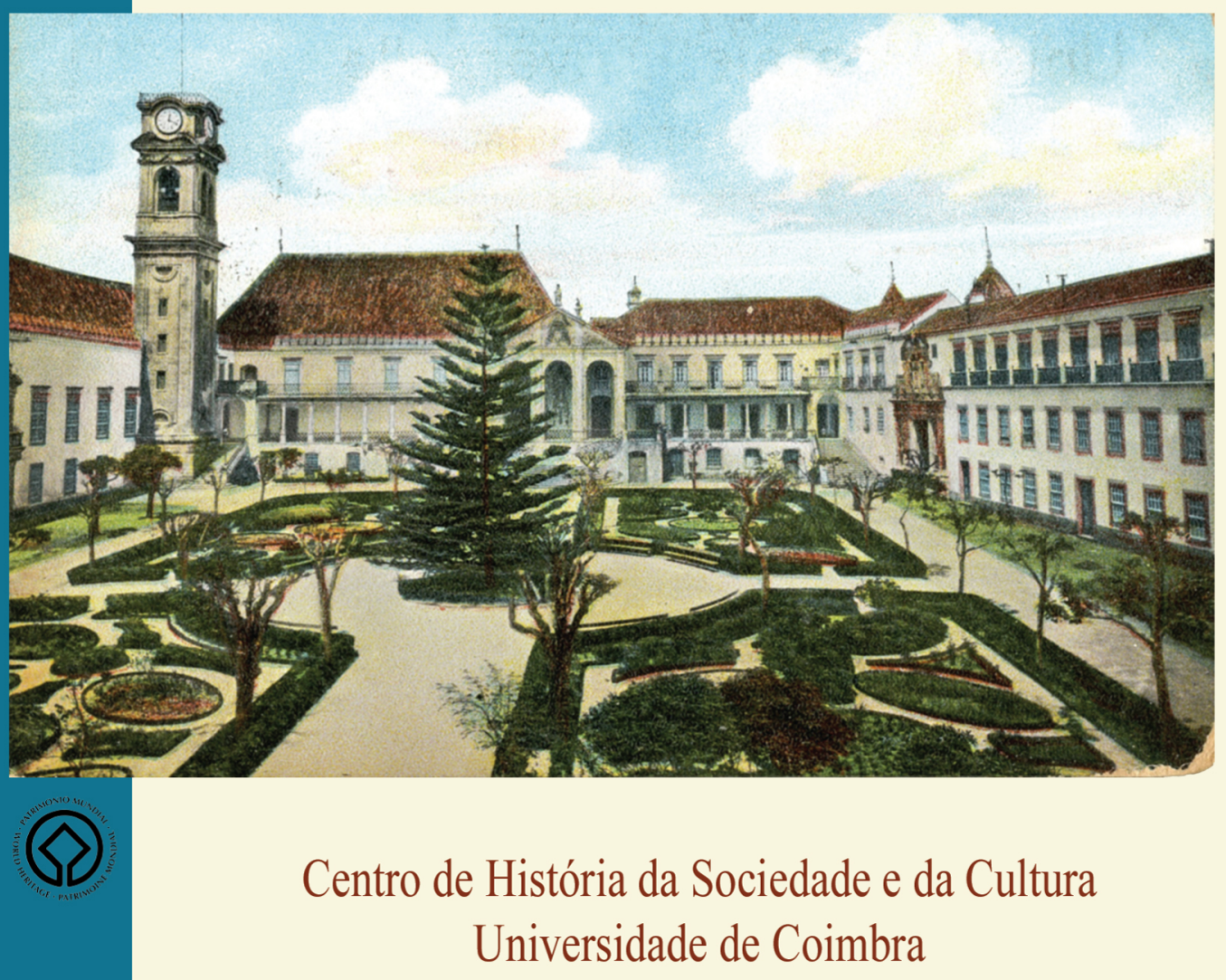

Coimbra 


\title{
Doutrinas e profilaxia da tuberculose em Portugal nos finais do século XIX
}

\author{
Ismael Cerqueira Vieira \\ CITCEM - Universidade do Porto \\ CEIS20 - Universidade de Coimbra \\ ismaelcerqvieira@gmail.com \\ Texto recebido em /Text submitted on: 09/05/2013 \\ Texto aprovado em /Text approved on: 30/09/2013
}

\section{Resumo/Abstract:}

A tuberculose é hoje tida como uma doença infetocontagiosa. Todavia, até finais do século XIX perseveraram duas doutrinas opostas, a da hereditariedade e a do contágio.

Mesmo após a revolução pasteuriana e as provas laboratoriais da infeto-contagiosidade demonstradas por Villemin (1865) e por Koch (1882), a comunidade médica portuguesa tardou em perfilhar o contagionismo da tuberculose mantendo-se fiel à doutrina da hereditariedade. Esta questão teve como consequência, além da errada formação dos médicos, o atraso das campanhas profiláticas num país pobre e fustigado pela tuberculose, que era das primeiras causas de morte em Portugal. Neste trabalho pretende-se discutir um tema antigo da medicina portuguesa, nomeadamente a difícil aceitação da doutrina da contagiosidade da tuberculose e a sua influência na prevenção organizada.

Today tuberculosis is regarded as an infectious and contagious disease. However until de late nineteenth century endured two opposing doctrines, the heredity and the contagion. Even before the Pasteurian revolution and laboratory evidences about the infectiousness and contagiousness demonstrated by Villemin (1865) and Koch (1882), the Portuguese medical community delayed to accept contagion of tuberculosis and stayed faithful to the doctrine of heredity. The consequences of that question resulted, besides the wrong training of doctors, in the delay of prophylactic campaigns in a poor country and harassed by tuberculosis, which was the first cause of death in Portugal. This paper aims to discuss a theme of old Portuguese medicine, in particular the difficult acceptance of the doctrine of contagiousness of tuberculosis and its influence in the organized prevention.

Palavras chave/Keywords:

Tuberculose; Medicina; Contágio; Hereditariedade; Profilaxia.

Tuberculosis; Medicine, Contagion, Heredity; Prophylaxis. 


\section{A génese da questão}

Desde a Antiguidade que a tuberculose está descrita pelos povos do mundo mediterrânico. Egípcios, hebreus, gregos e romanos, todos eles se reportavam a uma doença caracterizada pelo estado de magreza e pela expetoração sanguinolenta dos doentes - a tísica. Mesmo com descrições bastante detalhadas acerca da semiologia da doença, como fez Hipócrates de Cós, a verdade é que a natureza e a causa desta patologia nunca foram comprovadas cientificamente até à segunda metade do século XIX.

As duas teorias acerca da origem da tuberculose, a da hereditariedade e a do contágio, conhecem-se desde a Grécia Antiga: Hipócrates considerava que era hereditária, sendo célebre o seu aforismo "dum tísico nasce outro tísico", e os filósofos atomistas pré-socráticos e Galeno consideravam-na contagiosa defendendo que se propagava através de sementes, à semelhança do reino vegetal ${ }^{1}$.

A questão tomou outras proporções durante o Renascimento, quando em 1546 Girolamo Fracastoro de Florença advogou que a tísica era fruto do contágio pelos materiais emanados da respiração ou das secreções dos doentes tísicos por meio de animálculos. Inspirada nesta teoria a República de Lucca promulgou no século seguinte a primeira legislação de profilaxia da tísica de que há memória na Europa. Mas por volta de 1650, a Faculdade de Medicina de Paris sustentava a ideia de que a doença era hereditária.

No decorrer do século XVIII e impulsionado pela microscopia, o contributo mais destacado para a doutrina etiológica da tuberculose foi dado por Benjamin Marten, com a publicação em 1720 da obra «A New Theory of Consumption: More Especially of a Phthisis or a Consumption of the Lungs». Aí fez uma síntese das doutrinas etiológicas existentes, das explicações humorais às teorias físicas e mecânicas do seu século, mas verificou que não tinham fundamentação científica. Acreditava que a tísica podia ser causada por animálculos que se introduziam nas veias e eram levados pelo sangue para os pulmões, onde punham ovos que por sua vez provocavam

1 MARADONA HIDALGO, José Antonio - Tuberculosis: Historia de su conocimiento. Oviedo: Universidad de Oviedo, 2009, p. 30-32 e 51. 
obstruções, inflamação e ulceração dos tecidos ${ }^{2}$. A teoria dos animálculos de Marten teve alguns apoiantes como Cotton Mather de Boston, que ia mais longe ao considerar a possibilidade da quimioterapia contra os animálculos, e Thomas Reid que o citou na sua obra «Essay on the Phthisis Pulmonalis» ${ }^{3}$.

No dealbar do século XIX, com as reformas no ensino da medicina e com os trabalhos dos anatomopatologistas franceses, especialmente Corvisart, Bayle e Laennec, emergiu uma nova conceção de doença que correlacionava os sintomas ante mortem com as lesões post mortem. É neste sentido que o estudo da tísica e de outras doenças progrediu e fundamentou-se numa nova corrente de pensamento, que no entanto só trouxe conhecimentos válidos no campo do diagnóstico, da semiologia e da anatomopatologia ficando o problema etiológico adiado.

Em meados da centúria quando a utilização do microscópio passou a fazer parte do quotidiano dos cientistas, o estudo dos tecidos e das células dominou as pesquisas médicas. O tubérculo tornou-se assim o centro das atenções. Destacaram-se neste período os trabalhos de histologia e citologia do tubérculo de Hermann Lebert, de Benno Reinhard e de Rodolf Virchow. Este último, sendo o mais importante, acreditava que o tubérculo era um linfoma formado pela proliferação de tecido conjuntivo que se transformava em células pequenas com núcleo grosso ou em células gigantes multinucleares. No entanto persistiu o mistério sobre a origem do tubérculo ${ }^{4}$.

Foram as pesquisas laboratoriais, orientadas desde 1830 para o estudo da parasitologia, dos vírus, venenos obscuros e animálculos, que vieram aclarar a causa da doença. Em 1840, Hendel retomou a teoria dos animálculos e em 1857 Buhl afirmou a partir de evidências anatómicas que a tuberculose era provocada por um fator específico. Pouco tempo depois outros cientistas dedicaram-se ao isolamento das bactérias através da sua criação em culturas, sustentando que a saliva era um meio transmissor da bactéria.

2 DOETSCH, Raymond N. - Benjamin Marten and His "New Theory of Consumptions". Microbiological Reviews. V. 42:3 (1978) 521-528. (http://mmbr.asm.org/cgi/reprint/42/3/521. pdf consultado em 2012.02.15).

3 SHRYOCK, Richard Harrison - National Tuberculosis Association (1904-1954): A Study of the Voluntary Health Movement in the United States. Nova Iorque: Arno Press, 1977, p. 9.

4 ROCHA, Augusto - Sobre a evolução da doutrina da tuberculose. Coimbra Médica. 15:11 (1895) 165-169. 
Em 1865 Jean-Antoine Villemin provou a contagiosidade da doença pela inoculação de produtos da tuberculose humana em animais. Numa série de experiências realizadas em coelhos e porquinhos-da-índia provou que introduzindo no corpo destes animais fragmentos de substâncias tuberculosas eles adquiriam tuberculoses verdadeiras. Esta confirmação veio abalar todas as teorias sobre a natureza da tuberculose até então, acarretando também implicações práticas na profilaxia da moléstia ${ }^{5}$.

Mas foi Robert Koch o responsável pela descoberta do bacilo da tuberculose, batizado mais tarde com o seu nome: bacilo de Koch (BK). Em 1881 iniciou os trabalhos em torno da tuberculose no laboratório de Berlim com o material proveniente dum cadáver dum homem de trinta e dois anos. No ano seguinte fez o anúncio da grande descoberta à Sociedade de Fisiologia de Berlim a 24 de Março de 1882, demonstrando cientificamente que o BK era a causa única da tuberculose, sem o qual não existia a doença. Ficou igualmente provada a unidade da tuberculose, que podia afetar a maior parte dos órgãos, sistemas e tecidos. Esta descoberta não foi aceite unanimemente, uma vez que os opositores à teoria contagionista continuaram a negar a causa específica. Mas a verdade é que as pretensas causas da tuberculose como a má ventilação ou a má alimentação passaram a ser apenas condições que favoreciam o contágio ${ }^{6}$. Com o advento da bacteriologia modificou-se radicalmente o conceito etiopatológico da tuberculose, apesar de muitos médicos se manterem reticentes face às novas teorias.

No que diz respeito a Portugal, a medicina nacional foi sobretudo uma seguidora atenta dos trabalhos empreendidos no estrangeiro. Apesar de não ter dado um contributo original e decisivo à tisiologia, duma forma geral os médicos portugueses estiveram atualizados em relação às novidades surgidas das investigações estrangeiras, promovendo também o debate em torno dessas descobertas.

Os clássicos da medicina portuguesa, Amato Lusitano e Zacuto Lusitano, escreveram sobre a tísica em parâmetros enquadráveis na sua época. Ambos deram importância sobretudo às manifestações exteriores e percetí-

5 FREITAS, António Joaquim de - A tuberculose considerada sob o ponto de vista da contagiosidade e parasitismo. Porto: Imprensa Moderna, 1887. Tese Inaugural, p. 29-39.

6 ROCHA, Augusto - Sobre a evolução da doutrina da tuberculose. Coimbra Médica. 15:12 (1895) 185-189. 
veis da doença, dedicando particular atenção à semiologia. No entanto, Zacuto Lusitano e depois Ribeiro Sanches eram partidários da doutrina contagiosa de Fracastoro embora na sua altura reinasse uma certa confusão acerca da etiologia da doença? ${ }^{7}$.

Claramente contagionista era João Curvo Semedo, que no século XVIII escrevia na sua «Polyanthea Medicinal»:

Huma das cousas que encomendo muito aos Medicos modernos he que quando morrer algum tisico, fação logo queimar todas as roupas, e cousas do uso do tal tisico, porque não se pode explicar quam pegajosa seja esta doença; basta dizer que vi dous religiosos Trinos, que sendo moços, e robustos, se fizerão tisicos de morarem em huma cella em que, havia muitos annos, morrera um tisico. ${ }^{8}$

Este extrato mostra que Curvo Semedo considerava a tísica uma doença contagiosa, classificando-a de "pegajosa" e exemplificando com o caso de dois religiosos que contraíram a tísica por habitarem na cela que pertenceu a um tísico já falecido. Também Francisco Fonseca Henriques advogava a contagiosidade da moléstia, recomendando o isolamento dos tísicos e o afastamento das crianças e adolescentes dos doentes ${ }^{9}$. Por aqui se depreende que a teoria do contágio era conhecida pelos médicos portugueses, o que aconteceu até à transição do século XVIII para o XIX, afirmando-se a partir daí o anti-contagionismo e a teoria da hereditariedade que vigorou até às descobertas de Villemin e Koch.

\section{A difícil aceitação da teoria do contágio}

O difícil começo do século XIX em Portugal, marcado pelas invasões francesas, pela tutela inglesa e posterior guerra civil entre Absolutistas e Liberais, desarticulou os progressos nos vários domínios científicos,

7 MIRA, Matias Ferreira de e CARVALHO, Lopo de - La lutte contre la tuberculose au Portugal. Lisboa: ANT, 1936, p. 12-13.

8 SEMEDO, João Curvo - Polyanthea Medicinal. Lisboa: Officina dos Herdeiros de António Pedrozo Galram, 1741, p. 171-172.

9 CARVAlHO, Augusto da Silva - Apontamentos para a História da Tuberculose. Lisboa: Imprensa Médica, 1934. Sep. de «A Medicina Contemporânea», p. 13-17. 
medicina incluída. Na primeira metade do século XIX, Paris converteu-se no centro de maior desenvolvimento médico da altura o que atraiu vários portugueses exilados ou em viagens de formação. Foram vários os que fizeram da tuberculose o objeto de estudo da sua tese como José Albino Cardoso Geraldes, António da Costa Paiva, José Joaquim Pereira Reimão ou José Joaquim Barbosa. Por exemplo, António da Costa Paiva entendia que na génese do problema estava a má conformação do tórax e sobretudo a predisposição hereditária para adquirir a doença. Acreditava na curabilidade da tísica pulmonar e criticava a posição dos médicos portugueses retrógrados que não estavam atualizados em relação aos conhecimentos e técnicas de diagnóstico da altura.

Mas foram mormente os professores e alunos das Escolas Médico-cirúrgicas do Porto e Lisboa que contribuíram desde meados de Oitocentos de forma objetiva para a difusão dos conhecimentos da tuberculose, especialmente no que diz respeito à patologia e terapêutica ${ }^{10}$.

Podemos dizer que até à década de 1860, altura em que Villemin publicou os dados da sua investigação e provas concretas da inoculabilidade da tuberculose em animais, os médicos portugueses não partilhavam duma orientação doutrinária única relativa à natureza e origem da tuberculose. Em 1841, José Pereira Mendes baseado em casos de tuberculose infantil na Casa Pia de Lisboa defendeu a existência duma tísica própria da infância sediada nos brônquios. Segundo o autor a tísica brônquica era fruto da inflamação, ocorrendo em indivíduos predispostos hereditariamente e com temperamento linfático ${ }^{11}$, o que fazia dele partidário da teoria dos humores e da doutrina hereditária.

Em 1845, a «Gazeta Médica do Porto» publicou um artigo anónimo ${ }^{12}$ sobre a patologia das escrófulas (adenites tuberculosas) concebendo-a como uma doença de transmissão hereditária pelo casamento. No mesmo ano o

${ }^{10}$ A primeira tese em medicina escrita em Portugal sobre tuberculose data de 1857 , é manuscrita e provém da Escola Médico-cirúrgica do Porto. Versa sobre tuberculose cirúrgica, mais propriamente sobre a patologia e tratamento dos tumores brancos. Cf. PINTO, Albino Ribeiro-Algumas considerações sobre tumores brancos. Porto: [s.n.], 1857. Tese Inaugural.

${ }^{11}$ MENDES, José Pereira-Algumas considerações sobre huma especie de tisica propria da infancia. Jornal da Sociedade de Sciencias Medicas de Lisboa. 13 (1841) 8-15.

${ }^{12}$ ESCRÓFULAS. Gazeta Medica do Porto. 3 (1945) 244-246. 
Conselho de Saúde Pública do Reino publicou o quadro nosográfico ${ }^{13}$ oficial, no qual podemos verificar a confusão reinante ao nível da classificação da doença, senão vejamos: os "tubérculos", os "tubérculos pulmonares" e os "tubérculos mesentéricos" eram classificados individualmente como lesões orgânicas, as "escrófulas" eram tidas como lesões orgânicas locais, e os "tumores brancos" como tumores. Esta nosografia não faz qualquer menção à tísica ou à tuberculose, não a incluindo na quarta secção da Classe III respeitante às doenças de índole respiratória, o que evidencia o desconhecimento da natureza, da origem e diferentes formas da doença por parte dos médicos.

Em 1870 saiu uma portaria ${ }^{14}$ destinada a substituir o quadro nosográfico anterior, que identificava a tuberculose e as escrófulas como pertencendo à 1. a classe, correspondente às doenças gerais, conjuntamente com um enorme manancial de doenças, entre elas as infetocontagiosas como a cólera, febre tifoide, sarampo, escarlatina, etc. A tísica pulmonar figurava na $4 .{ }^{a}$ classe, correspondente às doenças do aparelho respiratório e os "tumores brancos" às doenças dos órgãos de locomoção. Verifica-se mais uma vez a pluralidade de vocábulos empregues para designar a tuberculose, denotando a ausência dum pensamento unicista em torno da doença. Não existia uma separação entre o que era a tuberculose, caracterizada pela presença de tubérculos nos pulmões, e de tísica pulmonar, identificada como doença marcada pela anorexia. Esta taxonomia é marcada pelos trabalhos dos patologistas e dos histologistas da primeira metade do século, que advogavam a existência duma pluralidade de doenças, que no entanto mais tarde se veio a descobrir que tinham o mesmo agente causal.

Um artigo datado de Setembro de 1858 afirmava que a tísica era o resultado duma discrasia ou da inflamação e outro artigo de 1866, com um título bastante sugestivo acerca do estado dos conhecimentos, atribuí os tubérculos à falta de ação do pâncreas sobre os ácidos gordos ${ }^{15}$.

${ }^{13}$ EDITAL de 31 de Dezembro de 1844: Quadro nosographico. Lisboa: Conselho de Saúde Pública do Reino. Gazeta Medica do Porto. 3 (1945) 141-144.

${ }^{14}$ PORTARIA de 12 de Dezembro de 1870 in Annaes de Saude Publica do Reino: Legislação Sanitária, 1. Lisboa: Imprensa Nacional, 1901, p. 110-118.

${ }^{15}$ Vide TUBERCULOSE pulmonar. Gazeta Médica de Lisboa. 6:137 (1858) 268-270 e MAIS uma etiologia do tubérculo. Gazeta Médica de Lisboa. 5 (1866) 138. 
Os ecos das experiências de Villemin rapidamente chegaram a Portugal, tendo-se publicado vários artigos com a descrição das suas experiências sobre a transmissibilidade da doença entre os animais. Fonssagrives e Guérin tornaram-se contagionistas declarados citando o facto de existirem casos de transmissão conjugal por coabitação, embora não considerassem a tísica como uma doença das mais contagiosas. É um facto comprovado que muitos artigos médicos da época tinham a preocupação de proteção social dos doentes, porque apesar de considerarem a tuberculose contagiosa e transmissível, tentavam dissimular a perigosidade da doença. Alegavam geralmente que não tinha uma incidência tão grave como outras doenças e chamavam à atenção para a não ostracização dos doentes nem a recusa de assistência, aconselhando concomitantemente a tomada de medidas preventivas ${ }^{16}$.

Mas a atitude para ignorar o contágio não era específica dos médicos portugueses. O historiador americano Richard Shryock ${ }^{17}$ afirmou que os médicos insistiam mais nas origens hereditárias da doença em detrimento do contágio, porque a tuberculose enquanto doença não reunia um conjunto de fatores que suscitava o medo em proporção idêntica às grandes epidemias. Mais do que a mortalidade real, o medo duma doença advinha do carácter repentino e violento, do grau de sofrimento que causava, da repulsa suscitada pelas sequelas e da capacidade desfigurante. Ora, a tuberculose sendo uma doença essencialmente crónica, cujos sintomas evoluíam gradualmente e cuja faceta mais visível era a anorexia, suscitava muito mais um sentimento de fatalismo e resignação do que uma histeria coletiva que levava à tomada de medidas imediatas e espontâneas como aconteceu com a peste bubónica ou a cólera. Esta atitude perante a tuberculose teve como efeito a lentidão na tomada de medidas preventivas, o que justifica a alta morbilidade, a elevada mortalidade e a dificuldade de defesa coletiva perante o problema.

A partir de 1882 publicaram-se vários artigos nos quais se confirmou a contagiosidade da doença nos animais, estabelecendo-se várias medidas de

${ }^{16}$ Ver a propósito destas posições os artigos publicados na Gazeta Médica de Lisboa: A TUBERCULOSE considerada como doença virulenta. Gazeta Médica de Lisboa. 5 (1866) 661-663, CONTAGIOSIBILIDADE da tisica. Gazeta Médica de Lisboa. 7 (1868) 135-136 e SOBRE a transmissão da tisica pulmonar. Gazeta Médica de Lisboa. 7 (1868) 298-299.

${ }^{17}$ Cf. SHRYOCK, Richard Harrison - National Tuberculosis..., cit, p. 37-39. 
higiene veterinária destinadas a evitar a propagação da enfermidade, mas as posições médicas relativamente ao contágio entre humanos mantiveram-se reservadas. A identificação do BK teve nos anos subsequentes uma difusão crescente no jornalismo médico português. No entanto, a Sociedade das Ciências Médicas de Lisboa, oficialmente não contagionista ${ }^{18}$, não se pronunciou acerca da descoberta de Koch no seu periódico durante cinco anos, o que levou Ricardo Jorge em $1883^{19}$ a criticar severamente o atraso da medicina nacional.

A primeira referência na imprensa médica portuguesa à descoberta do BK data de 30 de Março de 1882 na «Gazeta dos Hospitais Militares», apenas seis dias após a sua revelação. Também o «Correio Médico de Lisboa» e o «Coimbra Médica» noticiaram a contagiosidade da tísica e do seu micróbio. Silva $\mathrm{Amado}^{20}$ fez uma síntese das ideias contagionistas advogadas pelos médicos dos séculos XVIII e XIX, concluindo com a referência aos trabalhos de Koch. No artigo do «Coimbra Médica», assinado por $\mathrm{Nemo}^{21}$, o autor sublinhou a importância do diagnóstico pela bacterioscopia para a despistagem da doença, o papel da profilaxia para a limitação do contágio e a terapêutica, permaneceu contudo a dúvida sobre a curabilidade. Por esta altura Maximiano Lemos publicou um extenso artigo ${ }^{22}$ onde, depois de ter feito uma descrição histórica e exaustiva das pesquisas destinadas a provar o contágio e transmissibilidade em animais, mostrou-se defensor da doutrina do contágio porque só esta era experimentalmente conclusiva e válida.

Ao nível académico a maior parte das teses em medicina da década de 1870 e inícios da década de 1880 foram pródigas em afirmar a origem hereditária da doença, fosse pela transmissão direta e genética da doença de pais para filhos, fosse pela transmissão da predisposição à contração da

${ }^{18}$ BARROSA, Hernâni - O conceito da tuberculose na medicina portuguesa. Portugal Médico. 8:7 (1925) 293.

${ }^{19}$ Vide LEMOS JÚNIOR, Maximiano - Annuario dos Progressos da Medicina em Portugal: 1. ${ }^{\circ}$ Anno, 1883. Porto: Deposito Geral: Campos \& Godinho, 1884, p. iii-vi.

${ }^{20}$ AMADO, J. J. da Silva - A etiologia da tísica. O Correio Médico de Lisboa. 11:14 (1882) 134-135

${ }^{21}$ NEMO - O micróbio do tubérculo. Coimbra Médica. 3:15 (1883) 221-223.

${ }^{22}$ Cf. LEMOS JÚNIOR, Maximiano - Estudos sobre a tuberculose: o contágio e sua prophylaxia. A Medicina Contemporânea. 1:19, 21, 23, 24, 26, 28 e 30 (1883). 
doença: «não se nasce tuberculoso, mas tuberculizável $»^{23}$. Mas nenhuma das posições era extremista, pelo contrário várias delas eram híbridas, defendendo o predomínio da hereditariedade mas afirmando a possibilidade de existir o contágio em casos raros ou acidentais. Um bom exemplo desta linha de pensamento encontra-se na tese de concurso de António de Oliveira Monteiro onde apesar de falar das experiências de Villemin em torno da transmissão da tuberculose pela inoculação, recusava a admitir a origem contagiosa. Defendeu que a tísica tinha na sua origem causas internas inacessíveis à experimentação, jogando a diátese um papel preponderante ${ }^{24}$.

Por razões que desconhecemos, entre 1882 e 1887 só foi produzida uma única tese datada de 1885, que tratava da terapêutica da tísica pelas viagens marítimas e pelos climas quentes, não fazendo o autor qualquer menção à etiologia da doença. $\mathrm{O}$ vazio existente na produção académica sobre o tema da origem da tuberculose adiou a difusão da descoberta do bacilo de Koch durante cinco anos, sendo feita pela primeira vez em 1887 em três teses inaugurais, duas do Porto e uma em Lisboa. Em Lisboa, Manuel Gonçalves Marques $^{25}$ apresentou uma dissertação acerca da infeto-contagiosidade da tísica, defendendo convictamente a teoria do contágio operado pelo BK. Nas teses do Porto ${ }^{26}$ ambos os autores referem a descoberta de Koch e as repercussões das descobertas bacteriológicas ao nível da definição da verdadeira etiologia da tuberculose, confirmando a teoria do contágio, a natureza unitária e parasitária da doença. Apesar da lacuna temporal entre a descoberta de Koch e o aparecimento das suas conclusões em trabalhos universitários das escolas médicas portuguesas, a teoria do contágio criou raízes a que poucos ou nenhuns se atreviam a opor, muito embora a hereditariedade não desaparecesse por completo dos registos médicos.

${ }^{23}$ SOUSA, José Agostinho de - Breve estudo acerca da unidade da phthisica pulmonar. Lisboa, 1880. Tese de Inaugural, p. 42.

${ }^{24}$ MONTEIRO, António de Oliveira - Será a Phthisica pulmonar uma affecção contagiosa? Coimbra: Imprensa Litteraria, 1869. Tese de Concurso, p. 58-59.

${ }^{25}$ MARQUES, Manoel Gonçalves - Considerações sobre a infecto-contagiosidade da tuberculose. Lisboa: Typ. de Eduardo Roza, 1887. Tese Inaugural.

${ }^{26}$ Cf. GUIMARÃES, Rodrigo António Teixeira - O tratamento climaterico da tuberculose pulmonar e a Serra da Estrella. Porto: Typ. de A. J. da Silva Teixeira, 1887. Tese Inaugural e FREITAS, António Joaquim de - A tuberculose considerada sob o ponto de vista da contagiosidade e parasitismo. Porto: Imprensa Moderna, 1887. Tese Inaugural. 
Na viragem do século XIX para o XX, a discussão em torno da tuberculose herdada ou da tuberculose contraída constituía ainda um pomo de discórdia entre os médicos. A crença na tuberculose herdada subsistiu até tarde, não só pelo aspeto médico e científico, mas pelas questões sociais que acarretava. Considerar a tuberculose como uma doença estritamente contagiosa, num período em que ela era tão vulgar como a sua terapêutica ineficaz, podia gerar na população um sentimento de revolta que comprometesse a ordem social. Com a descoberta do BK, os médicos deixaram de poder afirmar que a tuberculose era hereditária por si só e por isso reconfiguraram as suas teorias. Surgiu na terminologia médica o "herdo-contágio" e a "herdo-predisposição".

A ideia de que a tuberculose era uma doença congénita e transmitida de pais para filhos, modificou-se ao longo dos anos e assumiu formas cada vez mais lógicas. A primeira evolução registada foi no sentido de se considerar não a hereditariedade da doença per se mas sim a hereditariedade da predisposição para contrair a moléstia. Os defensores da hereditariedade esforçaram-se por definir com precisão o papel da influência hereditária. Uns defendiam a herança do terreno, admitindo a transmissão de pais para filhos duma predisposição especial ligada a um conjunto de atributos físicos, químicos e dinâmicos que tornava os potenciais doentes mais acessíveis às influências do contágio: denominava-se "herdo-predisposição"27. Os médicos consideravam que várias doenças dos ascendentes, como o alcoolismo, a sífilis, as escrófulas ou a diabetes, levavam os descendentes a herdar "a virtualidade, a predisposição" 28 . Por outras palavras, não se nascia tuberculoso mas tuberculizável. Outros sustentavam a hereditariedade do gérmen, através do qual o bacilo era transmitido ao feto por meio dum contágio ante-partum, também conhecido por "herdo-contágio" ou herança bacilar $^{29}$. Os médicos que sustentavam esta posição admitiam que os micróbios patogénicos contidos no sangue da mãe passavam para a placenta

${ }^{27}$ MORA, Eduardo - Algumas palavras sobre as causas de tuberculose nas creanças. Lisboa: Typ. Minerva Central, 1894. Tese Inaugural, p. 20.

${ }^{28}$ CAMACHO, Manuel de Brito - A herança mórbida: apontamentos de hygiene. Lisboa: Tip. Eduardo Rosa, 1889. Tese de Inaugural, p. 21.

${ }^{29}$ MORA, Eduardo - Algumas palavras..., cit., p. 20 e CARVALHO, A. V. Campos de - Tuberculose e gestação. Coimbra: Typ. França Amado, 1896. Tese de Licenciatura, p. $78-79$. 
e consequentemente para o feto. Pelo lado paterno considerava-se também que o esperma bacilífero podia ser o responsável pela transmissão da doença. Por causa destas ideias nos anos finais do século XIX subsistia ainda uma conceção hereditária da tuberculose, mas em moldes distintos da existente antes dos estudos bacteriológicos.

Paulatinamente a classe médica nacional foi aceitando a nova doutrina contagionista, não só pela irrefutabilidade das provas como também pela afirmação da bacteriologia em Portugal que colheu vários cultores de renome. Se atendermos às teses produzidas nas escolas médicas portuguesas ${ }^{30}$ entre 1882, data da descoberta do BK, e 1901 é possível verificar que das cinquenta e sete dissertações, 33 delas defenderam como causa exclusiva o bacilo de Koch e o contágio como forma de transmissão, 4 teses defendiam a causa hereditária e 7 defendiam ambas. Das remanescentes, 7 não abordavam a questão da natureza ou da etiologia e das outras 6 só possuímos a referência bibliográfica uma vez que não se encontravam disponíveis para consulta. Significa isto que $58 \%$ dos autores defendiam o contágio, $7 \%$ defendiam a hereditariedade como a única causa e $12 \%$ consideravam ambas as possibilidades. Se tivermos em conta que este último grupo aceita o contágio, então temos $70 \%$ dos médicos a admitir a infeto-contagiosidade da tuberculose. Os autores que defendem unicamente a via de transmissão hereditária são minoritários, quatro em números absolutos, havendo uma incontestável afirmação das ideias contagionistas neste período. A partir de 1901 as menções à etiologia reportam-se exclusivamente ao bacilo de Koch como a causa única da tuberculose ${ }^{31}$.

${ }^{30}$ Estas teses dizem respeito às dissertações inaugurais, de concurso e doutoramento existentes nas bibliotecas das Faculdades de Medicina do Porto, Coimbra e Lisboa. Para uma descrição mais detalhada do estudo das teses em tisiologia, veja-se a nossa dissertação de doutoramento: VIEIRA, Ismael Cerqueira - Conhecer, tratar e combater a "peste branca". A tisiologia e a luta contra a tuberculose em Portugal (1853-1975). Porto: FLUP, 2012. Tese de Doutoramento.

${ }^{31}$ Cf. VIEIRA, Ismael Cerqueira - Conhecer, tratar e combater a "peste branca"..., p. $84-85$. 


\section{A profilaxia da tuberculose em tempo de incertezas científicas}

A lenta perceção e aceitação da natureza infetocontagiosa da tuberculose e a falta de medidas de prevenção e assistência tiveram efeitos epidemiológicos assinaláveis. Nos últimos decénios do século XIX, a tuberculose sob todas as formas era uma das principais responsáveis pela mortalidade nas principais cidades do país, ultrapassando todas as outras doenças infeciosas juntas. O Quadro 1 mostra a mortalidade comparada por tuberculose, doenças infetocontagiosas e demais doenças em Lisboa e no Porto, para o período em que é possível ter dados simultâneos antes da organização duma estatística verdadeiramente nacional, isto é 1893-1900.

Quadro 1 - Mortalidade geral nas cidades de Lisboa e Porto (1893-1900)

\begin{tabular}{|c|c|c|c|c|c|c|c|c|c|}
\hline \multicolumn{10}{|c|}{ Cidade de Lisboa } \\
\hline Causa de morte & 1893 & 1894 & 1895 & 1896 & 1897 & 1898 & 1899 & 1900 & Total \\
\hline Tuberculose ${ }^{\text {a) }}$ & 1580 & 1678 & 1828 & 1862 & 1574 & 1336 & 1201 & 1275 & 12334 \\
\hline Doenças infetocontagiosas ${ }^{\text {b) }}$ & 394 & 430 & 503 & 573 & 531 & 550 & 325 & 230 & 3536 \\
\hline Outras doenças ${ }^{\text {c) }}$ & 4844 & 5092 & 6016 & 6310 & 5386 & 3491 & 3331 & 3654 & 38124 \\
\hline Causas indeterminadas & 1188 & 1228 & 995 & 1276 & 1235 & 3944 & 3876 & 4046 & 17788 \\
\hline Total & 8006 & 8428 & 9342 & 10021 & 8726 & 9321 & 8733 & 9205 & 71782 \\
\hline \multicolumn{10}{|c|}{ Cidade do Porto } \\
\hline Causa de morte & 1893 & 1894 & 1895 & 1896 & 1897 & 1898 & 1899 & 1900 & Total \\
\hline Tuberculose ${ }^{\text {a) }}$ & 721 & 705 & 628 & 696 & 668 & 603 & 859 & 810 & 5690 \\
\hline Doenças infetocontagiosas b) & 358 & 408 & 190 & 254 & 381 & 450 & 725 & 191 & 2957 \\
\hline Outras doenças ${ }^{c)}$ & 3209 & 3053 & 2707 & 3316 & 2970 & 3002 & 3346 & 3027 & 24630 \\
\hline Causas indeterminadas & 565 & 567 & 515 & 742 & 615 & 623 & 693 & 596 & 4916 \\
\hline Total & 4853 & 4733 & 4040 & 5008 & 4634 & 4678 & 5623 & 4624 & 38193 \\
\hline
\end{tabular}

Fonte: Boletim mensal de estatística sanitária [Porto] (1893-1900) e Boletim de saúde e higiene municipal de Lisboa (1893-1900)

a) Agrupa tuberculose pulmonar, escrofulose e outras tuberculoses sem designação de sede.

b) Agrupa a febre tifoide, varíola, sarampo, escarlatina, coqueluche, difteria, garrotilho e "outras moléstias" epidémicas.

c) Agrupa 24 campos: cancro, meningite, apoplexia e amolecimento cerebral, eclampsia não puerperal, doenças do sistema nervoso, lesões do coração, doenças do aparelho circulatório, bronquite aguda, bronquite crónica, pneumonia e broncopneumonia, outras doenças do aparelho respiratório, moléstias do estômago, hérnias e obstruções intestinais, outras doenças do aparelho digestivo, cirrose do fígado, outras moléstias do fígado, nefrite e Mal de Bright, outras doenças do aparelho urinário, doenças dos órgãos genitais, septicemia puerperal, outras doenças puerperais, debilidade congénita e vícios de conformação, debilidade senil, suicídio, mortes violentas. 
Se atentarmos aos valores absolutos do Quadro 1 verificamos que as tuberculoses são uma das principais causas de morte, ultrapassando em Lisboa e Porto o total de todas as doenças infetocontagiosas. Em relação à mortalidade geral, a tuberculose representava cerca de $17 \%$ de todas as mortes na capital e cerca de 15\% no Porto entre 1893 e 1900. Devemos no entanto dizer que o número de mortes por tuberculose seria ainda maior se considerarmos que uma percentagem das mortes por causa indeterminada encobriam casos de tuberculose não diagnosticadas, por erro de diagnóstico ou propositadamente para esconder o que era considerado como uma doença socialmente estigmatizante ${ }^{32}$.

Apesar de caber às tuberculoses uma fatia considerável da mortalidade geral e de suplantar as principais doenças infetocontagiosas, muito pouco foi feito para preveni-la no século XIX. Sobre esta situação insurgiram-se higienistas como Miguel Bombarda e Tiago de Almeida que criticavam a inatividade do governo, que preferia gastar elevadas somas de dinheiro num sistema quarentenário dirigido a algumas epidemias que em nada se comparavam ao número de vítimas feitas pelo $\mathrm{BK}^{33}$.

Todavia, não se pode pensar que os médicos não tiveram consciência do problema, pois antes da teoria do contágio ser aceite já várias medidas preventivas haviam sido pensadas.

Se a Medicina não tem meios certos e seguros para dominar a diathese tuberculosa, depois da sua evolução, um dos seus ramos, a Hygiene, encerra em si elementos, que, oppurtunamente aproveitados, tem produzido óptimos benefícios, logrando sopear aquella manifestação diathesica.

[...] Se a herança é uma das causas, que mais poderosamente concorre para a propagação da pthysica, é claro que devemos occupar-

${ }^{32}$ Veja-se a propósito disto BIRABEN, Jean-Noël - La tuberculose et la dissimulation des causes de décès in BARDET, Jean-Pierre [et al.] - Peurs et terreurs face à la contagion: Choléra, tuberculose, syphilis (XIXe-XXe siècles). Paris: Fayard, 1988, p. 184-198.

${ }^{33}$ Cf. BOMBARDA, Miguel - Hospitalisação de Tuberculosos. Jornal da Sociedade das Sciencias Medicas de Lisboa. 61 (1897) 406-409 e ALMEIDA, Tiago de - A tuberculose em Vianna: necessidade de um sanatório. Jornal da Sociedade das Sciencias Medicas de Lisboa. 61 (1897) 65-68. 
nos, embora muito perfunctoriamente, d'uma questão delicada, o casamento, ponto de partida de tantas doenças chronicas. ${ }^{34}$

Este excerto chama à atenção para a problemática do casamento. Uma vez que a tuberculose era considerada hereditária e o casamento era tido como a única forma socialmente aceitável de enquadrar a reprodução, aquele tornou-se a origem do problema. Os casamentos impróprios eram "uma causa da degenerescência ethnica (...) que condenava a um viver miserável e a uma morte prematura as gerações que vão vindo" 35 . Os casamentos impróprios eram todos aqueles que se celebravam fruto de paixões exacerbadas, por conveniências familiares, casamentos em idades tardias, casamentos entre nubentes com idades muito desiguais, casamentos consanguíneos e casamentos entre um nubente são e um doente ou os dois doentes.

A idade aconselhada pelos médicos para o casamento era entre os 22 e os 45 anos para homens e entre os 17 e os 35 anos para as mulheres ${ }^{36}$. A partir destas faixas etárias considerava-se que o líquido espermático dos homens estava viciado pela velhice e os óvulos e o corpo da mulher impróprios para serem fecundados e transportar uma nova vida. Como consequência, os filhos dessas uniões nasciam com debilidade constitucional. Com a descoberta do BK, os médicos deixaram de poder afirmar que a tuberculose era hereditária, por isso o principal problema do casamento era o "herdo-contágio" e a "herança do terreno" de que já falamos anteriormente.

Nesta conceção entravam outros fatores causais que não só os casamentos em idade tardia ou casamentos entre doentes e sadios. Acreditava-se que doenças como a sífilis, a escrofulose e o alcoolismo eram responsáveis pela diátese tuberculosa. Mais tarde o despertar da consciência das más condições de vida dos pobres canalizou a atenção dos higienistas para os problemas da má alimentação, do modo de vida desregrado e da ignorância de preceitos higiénicos como fatores predisponentes à contração da tuberculose.

${ }^{34}$ CAMPOS, Joaquim Borges Garcia de - Demonstração anatomo-pathologica e clinica da curabilidade da pthysica pulmonar: seo tratamento prophylactyco. Porto: Typ. de José Coelho Ferreira, 1871. Tese Inaugural, p. 33-34.

${ }^{35}$ CAMACHO, Manuel de Brito - A herança morbida ..., cit., p. 6-7.

${ }^{36}$ CAMPOS, Joaquim Borges Garcia de - Demonstração anatomo-pathologica ..., cit., p. 34 . 
Impossibilitados de negar a etiologia microbiana pelas provas bacteriológicas, os médicos fizeram das condições de vida perniciosas o fulcro da questão causal da tuberculose e o ponto de partida da intervenção profilática. Uma vez que o casamento estava na base social da reprodução de potenciais doentes, as primeiras recomendações iam no sentido de proibir a contração do matrimónio aos tuberculosos. Um cônjuge infetava o outro e ambos produziriam uma descendência de tarados, inúteis e infelizes. Aqui o médico devia ter um papel ativo na obstrução dos casamentos perigosos. Uma vez consumado o casamento deveria haver por parte dos cônjuges medidas profiláticas. Egas Moniz na sua obra «A vida sexual» defendeu claramente que "Em casos de tuberculose não só deve haver separação de leitos, mas também separação de quarto [...] As relações sexuais devem ser abolidas" ${ }^{37}$.

Outros foram mais longe ao considerar que se devia praticar no Homem uma espécie de zootecnia semelhante à seleção realizada pelos criadores de gado para aperfeiçoar a raça ${ }^{38}$. Mas geralmente as indicações médicas iam no sentido das mulheres grávidas evitarem a doença ou a sua marcha. Eram sugeridos exercícios suaves, passeios, uso de vestidos cómodos e reforço da alimentação. As tuberculosas não deveriam amamentar, sendo preferível que o fizesse uma ama saudável. Nas classes pobres a má alimentação, o trabalho excessivo e a falta de resguardo perante as situações climatéricas eram apontadas como podendo afetar o desenvolvimento do feto e a sua constituição. Nas classes ricas era desaconselhado frequentar jantares, teatros e bailes durante a gravidez por se considerar também a existência duma certa "etiologia moral" da tuberculose. Viver desregradamente, ser alcoólico, ser prostituta ou frequentador de prostituição era meio caminho para ser candidato à tuberculose ${ }^{39}$.

Com a aceitação da contagiosidade os médicos insistiram noutros meios como a declaração obrigatória e na guerra ao bacilo, que por sua vez se desdobrava em múltiplas facetas.

${ }^{37}$ MONIZ, Egas - A vida sexual: physiologia e pathologia, 3. a ed. Lisboa: Ferreira Editores, 1913, p. 298.

${ }^{38}$ SIMÕES, Augusto Filipe - A civilisação, a educação e a phthisica. Lisboa: Livraria Ferreira, 1879, p. 48.

${ }^{39}$ BARNES, David S. - The making of social disease: tuberculosis in Nineteenth-Century France. Berkeley; Los Angeles; Londres: University of California Press, 1995, p. 76. 
A declaração obrigatória, isto é a obrigação legal dos médicos reportarem casos de tuberculose às autoridades, representava para muitos a derradeira forma de controlo da doença. Se fosse bem aplicada e se existissem meios de isolamento ou tratamento eficazes teria sido uma arma extraordinária contra a doença. Mas esta questão gerou uma enorme controvérsia entre os médicos porque atacava um dos princípios sagrados da medicina: a confidencialidade médico-paciente ${ }^{40}$. Em França um referendo promovido pelo «Journal des Praticiens» mostrou que 98,4\% dos médicos era contra a declaração obrigatória ${ }^{41}$.

A declaração obrigatória enformava vários problemas, desde logo o estigma social advindo do rótulo "tuberculoso". Além disso, os médicos alegavam ser uma violação do segredo profissional, como também a falta de um enquadramento assistencial alargado a todos os tuberculosos retirava qualquer utilidade à declaração. Existiam ainda outras questões pertinentes como a separação de pais e de filhos menores, as pesadas exigências financeiras para a eventualidade duma intervenção estatal no sentido do isolamento compulsivo e ainda as dificuldades impostas pelos meios tecnológicos que podiam levar a erros de diagnóstico. No essencial, a declaração obrigatória atacava não só o sigilo médico como a limitação das liberdades individuais. Somava-se a isto a pretensões de alguns higienistas em isolar os doentes e houve mesmo quem defendesse a criação de "tuberculosarias" à semelhança das leprosarias medievais ${ }^{42}$.

A legislação portuguesa em torno da declaração obrigatória da doença também não era muito evidente quanto à finalidade. Até ao final do século XIX conhecem-se três disposições legais nesse sentido. O primeiro é o Decreto de Lei n. ${ }^{\circ} 284$ de 3 de Dezembro de $1868^{43}$ que organizou o serviço superior de saúde pública, onde se pode ler no artigo 44. " "Todo o facultativo clínico, que observar qualquer caso de moléstia contagiosa, epidémica ou suspeita, dará parte do facto ao respectivo administrador do concelho, e em Lisboa e Porto aos commissarios de polícia civil". Contudo, devemos chamar

\footnotetext{
${ }^{40}$ BARNES, David S. - The making..., cit., p. 104.

${ }^{41}$ CASTANHEIRA, Acúrcio Gil Carvalho - Tuberculose pulmonar: sua história e profilaxia. Coimbra: Tip. Popular, 1919. Tese de Doutoramento, p. 21.

${ }^{42}$ BARNES, David S. - The making..., cit., p. 104-108.

${ }^{43}$ DECRETO n. ${ }^{\circ}$ 284/1868. D. de L. 284 (14-12-1868).
} 
à atenção para o facto de não prever nenhuma ação depois da notificação e em segundo lugar ela era desadequada no caso da tuberculose, uma vez que nesta data não era considerada uma doença contagiosa.

Em 1894, publica-se novo decreto ${ }^{44}$ por influência dum decreto francês semelhante promulgado um ano antes, visando a declaração de doenças contagiosas e evitáveis, com a finalidade de se proceder à desinfeção de habitações e objetos pertencentes aos falecidos devido às moléstias contagiosas. Apesar das boas intenções, o alcance desta medida pós-morte era limitada por não contemplar uma prevenção em vida do doente e restantes familiares. Decorrente destes decretos publicou-se em 1897 o «Regulamento de profilaxia contra o contágio da tuberculose ${ }^{45}$ do concelho da Guarda, que obrigava os proprietários de hotéis, hospedarias e casas de habitação a participar ao comissário de polícia civil a chegada de hóspedes, bem como ao comissário de polícia a matrícula de todos os doentes tuberculosos que se estabelecessem no concelho em busca de tratamento. Nenhum outro documento acerca da declaração dos casos de tuberculose se pode encontrar até à criação do «Regulamento geral dos serviços de saúde e beneficência pública» ${ }^{46}$ de 1901 , que introduziu a obrigatoriedade da declaração de doenças contagiosas incluindo a tuberculose, e do «Regulamento dos serviços de profilaxia da tuberculose» ${ }^{47}$ de 1902, a primeira legislação específica sobre profilaxia da tuberculose ao nível nacional.

Acerca da implementação da declaração obrigatória ficam muitas dúvidas, porque os benefícios não eram muito evidentes nem para os médicos nem para os pacientes. Divulgar o diagnóstico de tuberculose poderia equivaler à morte social dum doente, representando uma responsabilidade que nenhum médico queria assumir. Estudos interrompidos, carreiras

${ }^{44}$ DECRETO n. ${ }^{\circ}$ 83/1894. D. do G. 284 (14-04-1894).

${ }^{45}$ REGULAMENTO de prophylacia contra o contagio da tuberculose. Jornal da Sociedade das Sciencias Medicas de Lisboa. 61 (1897) 193-195 e NOVO regulamento dos tuberculosos da Guarda. Jornal da Sociedade das Sciencias Medicas de Lisboa. 61 (1897) 413-417.

${ }^{46}$ REGULAMENTO geral dos serviços de saúde e beneficência pública. D. do G. 292 (26-12-1901) p. 1031-1070.

${ }^{47}$ REGULAMENTO dos serviços de prophylaxia da tuberculose. D. do G. 198 (04-09-1902). 
destruídas, casamentos suspensos, laços sociais desfeitos eram algumas das consequências imediatas da declaração ${ }^{48}$.

Quanto ao sigilo médico existia uma enorme resistência dos clínicos na notificação pública da tuberculose dos seus pacientes. Isto liga-se não só à preservação duma deontologia própria, como também à manutenção da sua clientela burguesa, que não estava interessada em estar conotada a uma doença tida como da pobreza e da miséria.

Questões legais à parte, o combate contra a tuberculose foi essencialmente um combate contra o bacilo e como tal a aplicação da profilaxia procurava obstaculizar a progressão da doença pela tomada de medidas em determinados campos de saúde pública. Os principais temas diziam respeito à higiene alimentar, especialmente da carne e do leite de animais tuberculosos, à desinfeção de habitações e objetos e à campanha contra o escarro.

Com o reconhecimento da origem bacteriana da doença, a luta contra a tuberculose passou a ter como inimigo público n. ${ }^{\circ} 1$ o bacilo de Koch e com isto a propaganda antituberculose focou a sua atenção na prevenção do contacto direto ou indireto com o BK por meio de produtos infetados como a carne, o leite e os escarros secos.

Em 1865, Villemin tinham mostrado que a tuberculose era contagiosa e inoculável entre animais da mesma espécie e que o gado bovino era particularmente afetado ${ }^{49}$. Mais tarde concluiu-se que a tuberculose era transmissível entre animais e era veiculada pelo sangue, carne e leite ${ }^{50}$. Mas como a tuberculose causada pelo bacilo bovino nunca atingiu as proporções da tuberculose provocada pela estirpe humana, não lhe foi atribuída muita importância até se terem empreendido estudos consistentes sobre a transmissibilidade da doença do animal ao homem e sobre a infecciosidade dos produtos de origem animal. O Mycobacterium bovis entrava no corpo humano pela inalação, inoculação e ingestão de alimentos

${ }^{48}$ Cf. PÔRTO, Ângela - Representações sociais da tuberculose: estigma e preconceito. Rev. Saúde Publica. 41:1 (2007) 46 (http://www.scielo.br/pdf/rsp/v41s1/6493.pdf, consultado em 2012.10.09).

${ }^{49}$ VILLEMIN, Jean Antoine - Études sur la tuberculose: preuves rationnelles et expérimentales de sa spécificité et de son inoculabilité. Paris:J.-B. Baillière, 1868, p. 407 e 485 .

${ }^{50}$ DA TRANSMISSIBILIDADE da tuberculose por meio da carne e do leite de vaccas phthisicas. O Correio Médico de Lisboa. 10:5 (1881) 52. 
contaminados. A inalação de poeiras contendo os bacilos bovinos ou gotículas bacilíferas provenientes da respiração ou tosse do animal era possível, a par da inoculação possibilitada pela vacinação com produtos de bovinos tuberculosos no caso da vacina contra a varíola, mas era sobretudo pela ingestão de alimentos contaminados que se efetuava o contágio por via intestinal.

A ingestão de carne, sangue ou leite contaminado era perigoso sobretudo para as crianças que devido à menor resistência imunitária ficavam sujeitas à tuberculização por via intestinal. A infeção por via animal era responsável pelas tuberculoses intestinais, também designadas por peritonites tuberculosas, que podiam provocar obstruções intestinais agudas que requeriam intervenções cirúrgicas num curto espaço de tempo. Os médicos consideravam o bacilo bovino como o responsável por quase metade de todos os casos de meningite tuberculosa - a forma mais rápida e letal da doença - estando também associado à tuberculose osteoarticular, ganglionar e cutânea.

Em Portugal podemos fazer recuar a preocupação com a saúde do gado e com a prevenção da tuberculose bovina a 1862. O Decreto de 12 de Março de $1862^{51}$ veio dar poderes aos intendentes de pecuária para vigiar a sanidade do gado e prevenir epizootias e enzootias pelo combate à transmissão da doença. Cerca de duas décadas depois foi publicada a Portaria de 29 de Outubro de $1886^{52}$ que pretendia combater as doenças das espécies pecuárias transmissíveis ao homem pelo aumento da fiscalização das vacarias nas capitais de distrito e determinar os meios de fiscalização sanitária de carácter permanente a pôr em prática de modo a atenuar a transmissão da tuberculose $^{53}$. O problema da infeção por alimentos de origem bovina foi de tal modo encarado seriamente pelos médicos e veterinários que nos anos subsequentes gerou-se uma importante discussão científica acerca das medidas preventivas da tuberculose bovina, nomeadamente no Congresso da Tuberculose em 1895.

\footnotetext{
${ }^{51}$ REGULAMENTO das funcções dos veterinários. D. de L. n. ${ }^{\circ} 86$ (16-04-1862).

52 PORTARIA de 29 de Outubro. D. do G. n. ${ }^{\circ} 247$ (29-10-1886).

${ }^{53}$ ROCHA, Augusto - Policia Sanitaria. Coimbra Médica. 6:22 (1886) 337-339.
} 
A portaria de 1886 estabelecendo uma relação entre tuberculose humana e bovina, destinava-se a implementar medidas para a esterilização do leite de vaca. Em Portugal era prática corrente beber-se o leite acabado de mungir, encontrando-se nas ruas das cidades vendedores ambulantes que traziam atrás de si o animal, servindo o cliente em plena via pública. Existia também uma velha crença espalhada pelas províncias portuguesas de que o leite podia restituir a saúde aos tísicos e sob esse pretexto consumia-se o leite diretamente do úbere da vaca correndo o "risco de beber a morte no licor a que vão pedir a vida" 54 .

Impedir a expansão da tuberculose bovina e a sua transmissão ao homem implicava depurar as fontes de contágio. A pasteurização do leite pela ebulição era considerada o método mais eficaz. Ao nível da zoo-profilaxia, os médicos e veterinários insistiam na melhoria das condições higiénicas dos estábulos (iluminação, ventilação, remoção de imundices), na melhoria da alimentação dos animais ${ }^{55}$ e na utilização exclusiva de carnes estampilhadas ou carimbadas por um inspetor ${ }^{56}$.

No caso da carne, a esterilização pelo calor era o modo mais indicado, embora a profilaxia passasse também pela melhoria da higiene dos matadouros onde a contaminação se fazia por contacto das carnes boas com carnes bacilizadas, pelo contacto com mesas, facas e chão impregnado de bacilos $^{57}$. Todavia, implementar medidas profiláticas no campo da pecuária era difícil, porque além de ser um alimento importante e dificilmente desperdiçado, os interesses económicos dos negociantes esbarravam contra os ditames higiénicos. Conquanto o discurso de médicos e veterinários fosse no sentido de rejeitar carnes visivelmente tuberculizadas este era um assunto melindroso pela ingerência nos negócios dos criadores de gado ${ }^{58}$.

${ }^{54}$ NOGUEIRA, João Viegas Paula - A tuberculose animal nas suas relações com a tuberculose humana. Coimbra Médica. 15:16 (1895) 251.

55 SILVESTRE, A. Meliço - A higiene do leite na cidade de Coimbra. Coimbra Médica. 4:1 (1937) 88-106.

${ }^{56}$ CASTRO, Manuel de Seiça e - Luctando contra a Tuberculose. Famalicão: Typ. Minerva, 1909. Tese Inaugural, p. 56.

57 SANTOS, Geraldes dos - Lucta contra a tuberculose. Tuberculose: Boletim da Assistência Nacional aos Tuberculosos. 3:8 (1908) 39-45 e AS CARNES tuberculosas na difusão da tuberculose. A Medicina Contemporânea. 13:17 (1910) 133.

${ }^{58}$ NOGUEIRA, João Viegas Paula - A tuberculose animal..., cit., 256-257. 
Duma forma geral as análises aos produtos alimentares tinham consequências diretas na economia portuguesa. Tocar na reputação de alguns produtos como o vinho do Porto e mesmo na aguardente, no azeite ou no leite equivalia a avultados prejuízos, pelo que existia alguma cautela ao falar sobre o assunto. Assegurar um controlo eficaz neste domínio não seria fácil nem pacífico embora os laboratórios em atividade nos inícios do século XX dedicassem cerca de $70 \%$ da sua atividade à análise aos alimentos ${ }^{59}$.

Outra questão ligada à disseminação do bacilo e muito focada pelos médicos foi o hábito de escarrar. Nos finais do século XIX com a questão da poluição microbiana no auge, a grande preocupação dos higienistas centrou-se nos escarros dos tuberculosos. Era comum as pessoas escarrarem no chão, nas paredes, nos móveis, nos lenços ou na roupa: "Em Portugal escarra-se em toda a parte (escarra-se até na cabeça do visinho); o escarro secca, e esta perigosa poeira, carregada de micróbios e de toxinas tuberculosas, espalha-se por toda a parte" 60 .

Koch tinha descoberto que os escarros secos eram mais perigosos do que os húmidos, porque nestes os germes mantinham-se aglutinados. O escarro projetado no chão depois de seco ia para a atmosfera sob a forma de poeira, posto em movimento pelo vento, pelas vassouradas, pela sacudidela de tapetes ou pela limpeza dos móveis. Os processos de transmissão dos bacilos eram numerosos, desde a saliva para colar selos, aos bilhetes de cinema folheados com a ajuda dum dedo molhado em saliva, as canetas mordiscadas pelas empregadas de escritório ou o recém-nascido israelita contaminado pelo rabino tuberculoso que sugava o sangue do pénis do bebé depois da circuncisão ${ }^{61}$.

Contra esta forma de contaminação invisível a única solução era a prevenção. Para combater a nocividade dos escarros os higienistas defenderam duas formas de ação: existência de legislação que proibisse o escarro

${ }^{59}$ PEREIRA, Ana Leonor e PITA, João Rui - Pasteur in Portugal: public health and the diffusion of hygiene in RIEDE, Philip; PEREIRA, Ana Leonor; PITA, João Rui - História ecológico-institucional do corpo. Coimbra: Imprensa da Universidade de Coimbra, 2006, p. 25.

${ }^{60}$ SÁ, Joaquim Dias de - Luta contra a tuberculose. Porto: Typ. Minerva, 1901. Tese Inaugural, p. 48.

${ }^{61}$ DARMON, Pierre - É proibido escarrar in LE GOFF, Jacques [et al.] - As Doenças têm História. Lisboa: Terramar, 1997, p. 250. 
projetado diretamente no chão e a utilização de recetáculos (escarradores) que pudessem isolar e neutralizar a virulência do BK. Estes dois modos de ação não eram separáveis, na medida que a proibição de expetorar no chão implicava como alternativa a utilização de escarradores contendo substâncias antissépticas. Guilherme Ennes defendia que a ação profilática devia convergir para a esterilização dos escarros e para o asseio dos tuberculosos, porque tudo o resto era secundário ${ }^{62}$. A proteção da família do tuberculoso e da sociedade passava em grande medida pela assepsia, pelo asseio absoluto dos tuberculosos, pela supressão das poeiras e pelo uso dos escarradores públicos e portáteis.

A legislação portuguesa em torno deste assunto nunca foi muito prolixa e é difícil dizer se foi eficaz. Os primeiros regulamentos que proibiram a projeção de escarros no chão e exigiram a utilização de escarradores fixos ou portáteis foram promulgados na cidade da Guarda em 189763. Em 1901, António de Lancastre, que era então secretário-geral da ANT, escreveu um ofício ao governador civil de Lisboa, chamando à atenção para o problema do escarro como meio de transmissão da tuberculose. Nele diz que apesar do mau princípio de escarrar na via pública, se esta fosse bem iluminada os bacilos eram neutralizados pela luz solar. Um ano mais tarde o Governo Civil de Lisboa promulgou um edital ${ }^{64}$ onde proibia escarrar e cuspir nos transportes públicos e em locais públicos como templos, escolas, colégios, asilos, fábricas, hotéis, cafés, casas de espetáculos, hospitais, etc., devendo esses locais estarem apetrechados com escarradores. Cuspir fora deles era interdito e a violação do regulamento acarretava multas para os prevaricadores entre 500 e 1000 réis.

Contudo, a dificuldade de pôr em prática a regulamentação higiénica e a fiscalização dos comportamentos levou os médicos a apostar na divulgação de preceitos higiénicos através da imprensa escrita, de conferências, de editais ou através das homilias dos párocos, que eram instruídos nos

${ }^{62}$ ENNES, Guilherme José - Desinfecção domiciliaria em casos de tuberculose onde não haja desinfecção pública. A Medicina Moderna. 3:89 (1901) 167-168.

${ }^{63}$ REGULAMENTO de prophylacia..., cit., 193-195 e NOVO regulamento dos tuberculosos..., cit., 413-417.

${ }^{64}$ EDITAL de 14 de março de 1902 in Boletim dos serviços sanitários do Reino. Lisboa: Imprensa Nacional. 2 (1902) 8-9. 
seminários acerca das regras preventivas contra a terrível "peste branca". Neste domínio assumiu particular atenção a sensibilização para fazer uso de escarradores fixos ou de bolso. Estes deviam conter soluções antissépticas de formol, lisol, ácido fénico, creolina, ácido pirolenhoso para neutralizar a virulência dos bacilos ${ }^{65}$.

\section{Foto 1 - Escarrador portátil}

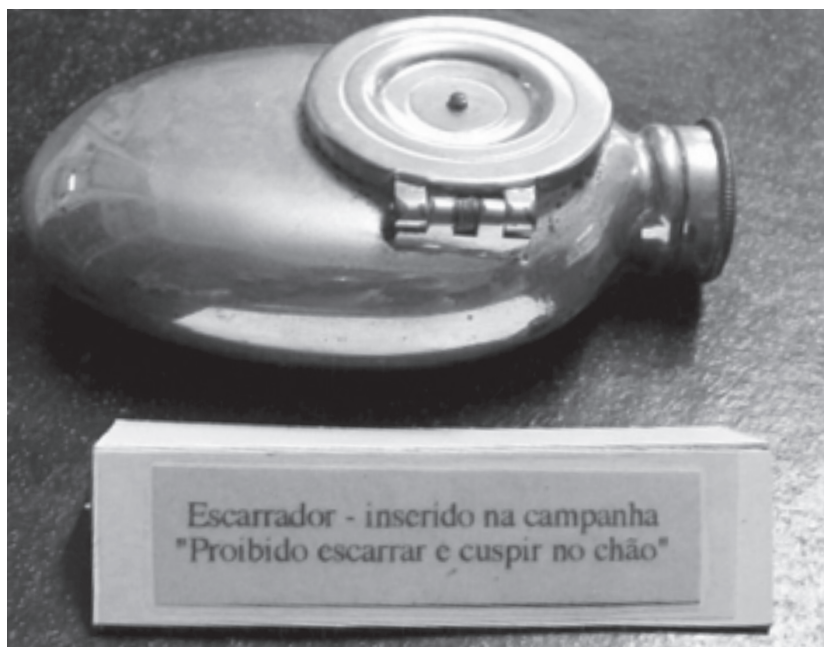

Fonte: Coleção do museu da Liga Portuguesa de Profilaxia Social. Foto de Ismael Vieira.

Paralelamente à preocupação com os produtos da expetoração dos tuberculosos, os higienistas recomendavam alguns cuidados especiais como a desinfeção da boca, a desinfeção das mãos, a desinfeção dos excrementos e matérias fecais, a desinfeção de brinquedos, mobílias, vidros, roupas de vestir e de cama de forma a proteger o maior número de pessoas da doença.

${ }^{65}$ ENNES, Guilherme - A desinfecção dos escarros. A Medicina Contemporânea. V. 1, n. 39 (1898) 318-319. 


\section{Conclusão}

Nos finais do século XIX, a tuberculose tornou-se um mal ubíquo na sociedade portuguesa e cuja natureza era incompreendida tanto pela população como pela classe médica. Apesar da importante descoberta do bacilo da tuberculose em 1882, a comunidade médica portuguesa tardou em aceitar resolutamente a natureza específica e contagiosa da doença. A tuberculose era considerada por muitos como uma doença da miséria, embora vitimasse ricos e pobre, e por isso fizeram dela um tabu social. Gradualmente a aceitação da teoria do contágio permitiu consciencializar os poderes públicos e médicos para a necessidade de intervir no sentido preventivo. Com isto gerou-se uma verdadeira "bacilofobia" porque o germe estava omnipresente nos alimentos, nos escarros, na saliva, no chão, nas paredes dos quartos, na roupa e na pele, desencadeando uma das maiores lutas do homem contra a doença de que há registo na História. Inicialmente foram adotadas medidas simples e possíveis para o conhecimento e tecnologia da altura, sendo que a insistência dos médicos na profilaxia mostra duas realidades: em primeiro lugar a consciência da necessidade de evitar o contágio pela prevenção e desinfeção e em segundo lugar a completa impotência terapêutica da medicina face a esta doença. Foi preciso esperar até à segunda metade do século XX para ver a mortalidade cair em Portugal. 